\title{
Silver Recovery from X-ray Film Waste by Leaching and Precipitation Method Using Sodium Hydroxide and Sodium Sulfide
}

\author{
Soja Siti Fatimah*, Wiwi Siswaningsih, Ali Kusrijadi, Fikri Aziz Shalahuddin \\ Departement of Chemistry Education, Faculty of Mathematics and Natural Science Education, Universitas \\ Pendidikan Indonesia, Kota Bandung, 40154 \\ *Corresponding author: soja_sf@upi.edu
}

Received: December 2019; Revision: January 2020; Accepted: May 2020; Available online: May 2020

\begin{abstract}
Silver recovery study from X-ray film waste by leaching and precipitation method using $\mathrm{NaOH}$ and $\mathrm{Na}_{2} \mathrm{~S}$ aims to determine the optimum conditions in silver recovery. The parameters optimated in this study were concentration of the precipitants, leaching temperature and effect of the type of precipitants on the precipitation time. The results showed that the $\mathrm{NaOH}$ and $\mathrm{Na}_{2} \mathrm{~S}$ precipitants were able to recover silver optimally at the concentration of $1.5 \mathrm{M}$. The optimum leaching temperature of the film with the $\mathrm{Na}_{2} \mathrm{~S}$ to recover silver was at $25{ }^{\circ} \mathrm{C}$, whereas in the $\mathrm{NaOH}$ the film leaching temperature only affected time of precipitation. Therefore, the formation of precipitate using $\mathrm{Na}_{2} \mathrm{~S}$ was more efficient than $\mathrm{NaOH}$, however the acquisition of silver was better in the use of $\mathrm{NaOH}$ than $\mathrm{Na}_{2} \mathrm{~S}$.
\end{abstract}

Keywords: X-ray film, Leaching, Precipitation, Recovery.

DOI: $10.15408 / j k v \cdot v 6 i 1.13648$

\section{INTRODUCTION}

$\mathrm{X}$-ray film has important role in medical use, especially in radiology. This film is widely used in providing a description of the anatomy of the body to diagnose whether there are abnormalities in the body or not. To get its picture, film processing is required. Icky (2011) stated that the processing of x-ray films consists of several stages, namely generating, rinsing, fixing, washing and drying. Among those stages, a very important stage in the formation of images on X-ray films is the Fixation.

The fixation stage in the processing of film, causing the silver halide compound $(\mathrm{AgBr})$ in the film bound and formed shadows on the film. This fixation process uses a binding solution named Fixer. Fixer solution is a chemical in the form of concentrated liquid which function is to dissolve silver halides in films that are not activated by light (Goaz and White, 1982). The X-ray film that has been processed leaves quite a lot of unexposed silver halide compounds. X-ray film is a double emulsion film consisting of transparent base material with adhesive coating, light sensitive emulsion, and protective coating on both surfaces (armymedical.tpub.com). Every $1 \mathrm{~m}^{2}$ of X-ray film that has been used or has been exposed to light contains about 3-3.5 $\mathrm{g}$ of silver. Whereas intact or unexposed X-ray films have an average silver content of 4-6 g / $\mathrm{m}^{2}$ (Khunpraset, 2008). This relatively high silver content would be beneficial if recovered perfectly with high percent recovery.

The relatively high silver content in the fixer solution and in the X-ray film can be grouped as B3 waste if it is discharged into the environment. The maximum limit of silver waste that can be discharged into the environment is $5.0 \mathrm{~g} / \mathrm{L}$ (PP no.85, 1999 about TCLP). Therefore, a recovery of fixer solution or X-ray film waste is needed.

There are several methods to recover silver from waste fixer solution including: metal replacement, electrolysis, and precipitation. The precipitation method is carried out by mixing fixer waste or $\mathrm{x}$-ray film with precipitant material (Kesumayadi, 2015). Some precipitant that can be used consist of 
Oxalic Acid, $\mathrm{NaOH}$, and $\mathrm{Na}_{2} \mathrm{~S}$ (Kesumayadi, 2015; Syed, 2002; Nakiboğlu, 2003).

The results of Kesumayadi's research (2015) showed that the precipitation method using $\mathrm{NaOH}$ and $\mathrm{Na}_{2} \mathrm{~S}$ with each $2 \mathrm{M}$ concentration, produced $16 \mathrm{~g}$ and $25 \mathrm{~g}$ silver respectively from 5 liters of saturated fixer solution waste. The use of $\mathrm{NaOH}$ or $\mathrm{Na}_{2} \mathrm{~S}$ as precipitating agent is due to the ability of sulfide and hydroxide which are effective for depositing silver (Lange and Triebel, 2000). The advantages of precipitation method using sodium hydroxide and sodium sulfide is because of its economical value (Kesumayadi, 2015), and its ease in the formation of deposits with silver elements based on the value of the results of its solubility (Chang, 2005). However, there is still few research conducted on the application of this deposition method to $\mathrm{X}$-ray films, especially for the use of $\mathrm{Na}_{2} \mathrm{~S}$ as precipitating material. In fact, based on the $\mathrm{Ksp} \mathrm{Na}_{2} \mathrm{~S}$ value which is very small (Svehla, 1985), $\mathrm{Na}_{2} \mathrm{~S}$ is considered to be very effective for depositing silver.

Other research conducted by Syed (2002) and Canda (2017), focused on the leaching method in recover silver from $\mathrm{X}$-ray films. Syed (2002) reported that from $4 \mathrm{~kg}$ of $\mathrm{X}$-ray film silver recover was successfully performed with recovery percentage of $97 \%$ (41 g) under optimal condition using oxalic acid. However, the use of oxalic acid as a precipient in this leaching method can cause the formation of dangerous and explosive compounds, namely silver oxalate. Canda et al., (2017) conducted a study to recover silver from X-ray films using Aqueous $\mathrm{NaOH}$ Solution. The silver obtained was $6.54 \mathrm{~g}$ from $1 \mathrm{~kg}$ of X-ray film. However, this study only focused on using one reagent, $\mathrm{NaOH}$. Beside that, his research also focus on the effect of $\mathrm{NaOH}$ concentration to the film's leaching time.

Therefore, based on those problems this study aims to recover silver from X-ray film waste by using $\mathrm{NaOH}$ and $\mathrm{Na}_{2} \mathrm{~S}$ reagents.

\section{MATERIALS AND METHODS Materials and Instrumentation}

The Instrumentation used in this study are beaker glass and magnetic stirrer. Analysis of silver content (ppm) in the filtrate are using Atomic Absorption Spectroscopy (AAS). Analysis of silver content in precipitate was determined using XRF. The material used in the study was X-ray film waste from one of the clinical laboratories in Bandung.

\section{Procedures}

The study of silver recovery from X-ray film waste consists of 3 stages. The first stage was the leaching of X-ray film $2 \times 2 \mathrm{~cm}^{2}$ using precipitating reagents. The film was dissolved with 2 different types of reagents, $\mathrm{NaOH}$ and $\mathrm{Na}_{2} \mathrm{~S}$. The concentration of $\mathrm{NaOH}$ used was $1 \mathrm{M} ; 1.5 \mathrm{M} ; 2 \mathrm{M} ; 2.5 \mathrm{M}$, and the concentration of $\mathrm{Na}_{2} \mathrm{~S}$ used was $1.5 \mathrm{M} ; 2 \mathrm{M} ; 2.5 \mathrm{M} ; 3 \mathrm{M} ; 3.5 \mathrm{M}$. The second stage was the deposition of leaching product for 48 hours. Then the separation of precipitated solution was carried out to obtain precipitate and filtrate. The third stage was analysis. These experiment was one time repeated because the limitation of materials.

The precipitate was weighed to determine its mass then burned, while the filtrate was analyzed with AAS to determine the remaining silver content. Part of the precipitate from each reagent was used for the analysis of the silver content using XRF.

The maximum concentration and leaching temperature was determined based on precipitate mass, while the optimum concentration and leaching temperature is determined based on the remaining silver content in the filtrate.

\section{RESULT AND DISCUSSION}

Theoretically the silver recovery method in this study is based on the precipitation reaction between $\mathrm{NaOH}$ and $\mathrm{Na}_{2} \mathrm{~S}$ with silver which can produce silver (I) oxide $\left(\mathrm{Ag}_{2} \mathrm{O}\right)$ and silver (I) sulfide $\left(\mathrm{Ag}_{2} \mathrm{~S}\right)$ (Svehla, 1985), according to the following reaction equation 1 and 2 .

This precipitation method is used based on the fact that silver compounds easily precipitate in the presence of hydroxide and sulfide ions in water at $25^{\circ} \mathrm{C}$ (Chang, 2008).

$$
\begin{aligned}
& 2 \mathrm{Ag}^{+}{ }_{(\mathrm{aq})}+2 \mathrm{OH}_{(\mathrm{aq})}^{-} \rightarrow \mathrm{Ag}_{2} \mathrm{O}_{(\mathrm{s})}+\mathrm{H}_{2} \mathrm{O}_{(\mathrm{l})} \\
& \mathrm{Ag}^{+}{ }_{(\mathrm{aq})}+\mathrm{S}^{2-}{ }_{(\mathrm{aq})} \rightarrow \mathrm{Ag}_{2} \mathrm{~S}_{(\mathrm{s})}
\end{aligned}
$$

$$
\begin{aligned}
& \mathrm{K}_{\mathrm{sp}}=1.52 \times 10^{-8} \\
& \mathrm{~K}_{\mathrm{sp}}=6.0 \times 10^{-50}
\end{aligned}
$$




\section{Leaching Results}

The perfect leaching of the film by the precipitating reagent marked by colour changing of the film from purple to transparent blue (Canda et al., 2018). Based on experiment conducted on the process of leaching $2 \times 2 \mathrm{~cm}^{2}$ $\mathrm{x}$-ray film using $\mathrm{Na}_{2} \mathrm{~S}$ reagent at various concentrations and temperatures, the results showed the time required to leach $2 \times 2 \mathrm{~cm}^{2} \mathrm{X}$ ray film has tendency to be faster as concentration of $\mathrm{Na}_{2} \mathrm{~S}$ reagent and leaching temperature increased. However, the leaching time was not affecting the obtained silver or precipitate. This was because the leaching only produces brownish black suspension of silver halide with precipitant, not producing a precipitate or silver. The time of dissolution of X-ray films with $\mathrm{Na}_{2} \mathrm{~S}$ on various concentrations and temperature is presented in Tables 1 and 2 . The data was obtained by making one of the variable constant. The time of dissolution of X-ray films with $\mathrm{NaOH}$ at various concentrations and temperatures is presented in Tables 3 and 4.

Table 1. Time data of the X-ray films leaching using $\mathrm{Na}_{2} \mathrm{~S}$ with variation of concentration in room temperature

\begin{tabular}{ccc}
\hline $\begin{array}{c}\text { Film mass } \\
(\mathbf{g})\end{array}$ & $\begin{array}{c}\mathbf{N a}_{2} \mathbf{S} \\
\text { Concentration } \\
(\mathbf{M})\end{array}$ & $\begin{array}{c}\text { Leaching time } \\
\text { (Minutes) }\end{array}$ \\
\hline 50 & 1.5 & 42 \\
50 & 2 & 32 \\
50 & 2.5 & 15 \\
50 & 3 & 14 \\
50 & 3.5 & 13 \\
\hline
\end{tabular}

Table 2. Time data of X-ray film leaching using $1.5 \mathrm{M} \mathrm{Na}_{2} \mathrm{~S}$ with variation of temperature

\begin{tabular}{ccc}
\hline $\begin{array}{c}\text { Film mass } \\
(\mathbf{g})\end{array}$ & $\begin{array}{c}\text { Temperature } \\
\left({ }^{\circ} \mathbf{C}\right)\end{array}$ & $\begin{array}{c}\text { Leaching } \\
\text { time } \\
(\text { Minutes })\end{array}$ \\
\hline 25 & 25 & 15 \\
25 & 40 & 12 \\
25 & 60 & 11 \\
25 & 80 & 10 \\
25 & 25 & 15 \\
\hline
\end{tabular}

Based on table 1 to table 4 , in $\mathrm{NaOH}$ reagent, the leaching time also offered the same tendency with the $\mathrm{Na}_{2} \mathrm{~S}$ reagent, the increased concentration and temperature offered the faster time required to leach the Xray film. Based on the result of Canda's research (2017), the optimum concentration and leaching temperature using $\mathrm{NaOH}$ reagent was $1.5 \mathrm{M}$ with the temperature above $60^{\circ} \mathrm{C}$. However, $\mathrm{Na}_{2} \mathrm{~S}$ could leach film slightly more efficient than $\mathrm{NaOH}$. This is due to the smaller Ksp of $\mathrm{Na}_{2} \mathrm{~S}$, so that the formation of precipitate is more efficient. In addition, in the formation of $\mathrm{Ag}_{2} \mathrm{O}$ where $\mathrm{Ag}_{2} \mathrm{O}$ is also formed from $\mathrm{AgOH}$ equilibrium, the ability of $\mathrm{OH}^{-}$to bind $\mathrm{Ag}$ is smaller than the ability of $\mathrm{S}_{2}^{-}$bind $\mathrm{Ag}$ as shown in the equations (1) and (2).

Table 3. Time data of the X-Ray film leaching using $\mathrm{NaOH}$ with variation of concentration in room temperature

\begin{tabular}{ccc}
\hline $\begin{array}{c}\text { Film mass } \\
(\mathrm{g})\end{array}$ & $\begin{array}{c}\text { NaOH } \\
\text { Concentration } \\
\left({ }^{\mathbf{0}} \mathbf{C}\right)\end{array}$ & $\begin{array}{c}\text { Leaching } \\
\text { time } \\
(\text { Minutes })\end{array}$ \\
\hline 50 & 1 & 80 \\
50 & 1.5 & 45 \\
50 & 2 & 36 \\
50 & 2.5 & 25 \\
\hline
\end{tabular}

Table 4. Data on the time of X-ray film leaching using $1.5 \mathrm{M} \mathrm{NaOH}$ with variation of temperature

\begin{tabular}{ccc}
\hline $\begin{array}{c}\text { Film mass } \\
(\mathbf{g})\end{array}$ & $\begin{array}{c}\text { Temperature } \\
\left({ }^{\circ} \mathbf{C}\right)\end{array}$ & $\begin{array}{c}\text { Leaching } \\
\text { time } \\
(\text { Minutes })\end{array}$ \\
\hline 25 & 25 & 24 \\
25 & 40 & 20 \\
25 & 60 & 15 \\
\hline
\end{tabular}

\section{Precipitation Results}

The precipitation process with $\mathrm{NaOH}$ and $\mathrm{Na}_{2} \mathrm{~S}$ can produce $\mathrm{Ag}_{2} \mathrm{O}$ and $\mathrm{Ag}_{2} \mathrm{~S}$ precipitate (Svehla, 1985), following the equation (1) and (2). In the study that has been done, two types of precipitate from the results of perfect precipitation and separation was obtained, one was black precipitate and other was gray colored precipitate.

Based on the literature (Svehla, 1985), the precipitate obtained is successively in accordance with the characteristics of $\mathrm{Ag}_{2} \mathrm{~S}$ and $\mathrm{Ag}_{2} \mathrm{O}$ precipitate. The precipitate obtained was burned using a flame gun to obtain pure silver. In addition, some precipitate were 
analyzed using X-ray fluorescene (XRF) to determine the silver content. The filtrate was then analyzed using Atomic Absorption Spectroscopy (AAS) to further analysis on the possibility of silver in the filtrate that might not precipitate.

The weighted mass of the precipitate obtained and the results of the analysis of the filtrate using AAS were used as a reference to determine the optimum concentration of the precipitation and the optimum temperature of the leaching.

\section{Effect of $\mathrm{NaOH}$ Concentration on Silver Recovery}

In determining the effect of concentration on silver recovery, the precipitate mass obtained and filtrate analyzed using AAS are the variables that determine the optimum concentration. In determining the optimum concentration of $\mathrm{NaOH}$ with variations of $1 \mathrm{M}, 1.5 \mathrm{M}, 2 \mathrm{M}$, and $2.5 \mathrm{M}$ concentrations, the results showed that the most precipitate obtained was at $1.5 \mathrm{M}$ concentration with a total precipitate of 1.9018 $\mathrm{g}$ from $50.0765 \mathrm{~g}$ of X-ray film, and based on analysis silver content in the filtrate using AAS, $1.5 \mathrm{M} \mathrm{NaOH}$ concentration is the most effective reagent also in recovering silver from the film, which leaves silver in the filtrate as much as $12 \mathrm{ppm}$. The results of the precipitate mass and silver content in the filtrate show the appropriate data alignment, so based on these results, the optimum concentration of $\mathrm{NaOH}$ for silver recovery is $1.5 \mathrm{M}$. This result was corresponding with the literature (Canda et al., 2017) that the optimum concentration is $1.5 \mathrm{M}$. Table 5 shows the data obtained from the precipitation and analysis of silver content in the filtrate using AAS.

Table 5. Data of precipitate mass and silver content in filtrate using $\mathrm{NaOH}$ with variations of concentration

\begin{tabular}{cccc}
\hline $\begin{array}{c}\text { Film } \\
\text { Mass } \\
(\mathbf{g})\end{array}$ & $\begin{array}{c}{[\mathbf{N a O H}]} \\
(\mathbf{M})\end{array}$ & $\begin{array}{c}\text { Precipitate } \\
\text { Mass }(\mathrm{g})\end{array}$ & $\begin{array}{c}\text { Silver in } \\
\text { Filtrate } \\
(\mathbf{p p m})\end{array}$ \\
\hline 50 & 1 & 0.8346 & 26.16 \\
50 & 1.5 & 1.9018 & 12 \\
50 & 2 & 1.7249 & 33.84 \\
50 & 2.5 & 1.1611 & 30.16 \\
\hline
\end{tabular}

The data obtained pointing to the deficiency that after concentration of $1.5 \mathrm{M}$ $\mathrm{NaOH}$ the next precipitate mass will be decrease. Therefore, the optimal $\mathrm{NaOH}$ concentration which can obtain optimal precipitate mass is $1.5 \mathrm{M}$. The following plot data on the concentration of $\mathrm{NaOH}$ with the precipitate mass obtained.

\section{Effect of $\mathrm{Na}_{2} \mathrm{~S}$ Concentration on Silver Recovery}

In the use of $\mathrm{Na}_{2} \mathrm{~S}$, the maximum precipitate mass was obtained at concentration of $2.5 \mathrm{M}$, which was $1.0499 \mathrm{~g}$. While the minimum precipitate mass was obtained at the concentration of $1.5 \mathrm{M}$. However, based on the analysis of silver content in the filtrate using AAS, showed that the most recovered silver was at a concentration of $1.5 \mathrm{M}$ not at the concentration of $2.5 \mathrm{M}$. This means that in the use of $\mathrm{Na}_{2} \mathrm{~S}$ reagents, the mass of precipitate obtained did not associate with recovered silver. This was because in the precipitate, it is possible to form sulfur precipitate as impurities, where the number of this imputrities affects the mass of the precipitate obtained. The existence of sulfur precipitate is also proven by the presence of yellow precipitate when the precipitate burned using a flame gun. Therefore, the optimum concentration of $\mathrm{Na}_{2} \mathrm{~S}$ reagent is at the concentration of $1.5 \mathrm{M}$. This result can not be compared with the literature (Kesumayadi, 2015), because the concentration of $\mathrm{Na}_{2} \mathrm{~S}$ used was one concentration $(2 \mathrm{M})$. The following presented data shows the association between the mass of precipitate obtained and the silver content in the filtrate using $\mathrm{Na}_{2} \mathrm{~S}$ precipitant in table 6 .

Table 6. Data of precipitate mass and silver content in filtrate using $\mathrm{Na}_{2} \mathrm{~S}$ with variations of concentration.

\begin{tabular}{cccc}
\hline $\begin{array}{c}\text { Film } \\
\text { Mass } \\
(\mathbf{g})\end{array}$ & $\begin{array}{c}{\left[\mathbf{N a}_{2} \mathbf{S}\right]} \\
(\mathbf{M})\end{array}$ & $\begin{array}{c}\text { Precipitate } \\
\text { Mass (g) }\end{array}$ & $\begin{array}{c}\text { Ag in } \\
\text { Filtrate } \\
(\mathbf{p p m})\end{array}$ \\
\hline 50 & 1.5 & 0.3151 & 1140 \\
50 & 2 & 0.4513 & 2560 \\
50 & 2.5 & 1.0499 & 2212 \\
50 & 3 & 0.5973 & 2411 \\
50 & 3.5 & 0.7657 & 2179 \\
\hline
\end{tabular}




\section{Effect of $\mathrm{NaOH}$ Precipitation Temperature on Silver Recovery}

Based on the results obtained in table 7 , in the use of $\mathrm{NaOH}$, the optimum silver recovey was at leaching temperature of $80{ }^{\circ} \mathrm{C}$, with the remaining silver content of $2.6 \mathrm{ppm}$. These results are seen based on the silver content remaining in the filtrate only, the mass of the precipitate obtained using $\mathrm{NaOH}$ reagent with the film leaching temperature did not show significant effect. This result was corresponding with literature (Canda et al., 2017) that the optimum temperature was above $60{ }^{\circ} \mathrm{C}$. The following data on table 7 shows the association between precipitate mass and silver content in the filtrate at temperature variations.

Table 7. Data of precipitate mass and silver content in filtrate using $\mathrm{NaOH}$ with variation of leaching temperature

\begin{tabular}{cccc}
\hline $\begin{array}{c}\text { Film } \\
\text { Mass } \\
(\mathbf{g})\end{array}$ & $\begin{array}{c}\text { Temperature } \\
\left({ }^{\mathbf{C}} \mathbf{C}\right)\end{array}$ & $\begin{array}{c}\text { Precipitate } \\
\text { Mass }(\mathbf{g})\end{array}$ & $\begin{array}{c}\text { Ag in } \\
\text { Filtrate } \\
(\mathbf{p p m})\end{array}$ \\
\hline 25 & 25 & 0.6509 & 3 \\
25 & 40 & 0.6686 & 8 \\
25 & 60 & 0.6336 & 4.17 \\
25 & 80 & 0.6756 & 2.6 \\
\hline
\end{tabular}

\section{Effect of $\mathrm{Na}_{2} \mathrm{~S}$ Precipitation Temperature on Silver Recovery}

Table 8. Data of precipitation mass and silver content in precipitate using $\mathrm{Na}_{2} \mathrm{~S}$ with variations of leaching temperature.

\begin{tabular}{cccc}
\hline $\begin{array}{c}\text { Film } \\
\text { Mass (g) }\end{array}$ & $\begin{array}{c}\text { Temperat } \\
\text { ure }\left({ }^{\circ} \mathbf{C}\right)\end{array}$ & $\begin{array}{c}\text { Precipitate } \\
\text { Mass (g) }\end{array}$ & $\begin{array}{c}\text { Ag in } \\
\text { Filtrate } \\
(\mathbf{p p m})\end{array}$ \\
\hline 25.0060 & 25 & 0.5972 & 1019 \\
25.0051 & 40 & 0.7269 & 1112 \\
25.0041 & 60 & 1.0848 & 1146 \\
25.0003 & 80 & 0.9881 & 1490 \\
\hline
\end{tabular}

In the use of $\mathrm{Na}_{2} \mathrm{~S}$ reagent, the optimum leaching temperature was at $25{ }^{\circ} \mathrm{C}$. Where based on the silver content in the filtrate at room temperature, the remaining silver was equal to $1019 \mathrm{ppm}$, while the optimum mass obtained by leaching was $60{ }^{\circ} \mathrm{C}$ with a mass of 1.0848 grams. However, the mass gain of these precipitate was not entirely proportional to the amount of silver recovered in the use of $\mathrm{Na}_{2} \mathrm{~S}$ reagent. That is because of the possibility of the formation of sulfur precipitate that affect the mass of the precipitate. Therefore the optimum leaching temperature with $\mathrm{Na}_{2} \mathrm{~S}$ precipitating was at 25 ${ }^{\circ} \mathrm{C}$. Table 8 shows the association between the precipitate mass obtained and the remaining silver content in the filtrate with the $\mathrm{Na}_{2} \mathrm{~S}$ reagent with variations of temperature.

\section{Effect of Precipitant Types on Precipitation Time}

The precipitation time of the leaching product was affected by the type of precipitant used, that is $\mathrm{NaOH}$ and $\mathrm{Na}_{2} \mathrm{~S}$. Based on the comparison results obtained, $\mathrm{Na}_{2} \mathrm{~S}$ reagent can precipitate faster than $\mathrm{NaOH}$ reagent, where the time required to completely precipitating product was two days for sodium sulfide, and 7 days for sodium hydroxide. The rate of precipitation was influenced by the $\mathrm{Ksp}$ of $\mathrm{Ag}_{2} \mathrm{~S}$ and $\mathrm{Ag}_{2} \mathrm{O}$, where the $\mathrm{K}_{\text {sp }} \mathrm{Ag}_{2} \mathrm{~S}$ value is smaller than the $\mathrm{Ksp} \mathrm{Ag}_{2} \mathrm{O}$, which is $6.0 \times 10^{-50}$ and $1.52 \times 10^{-8}$, respectively.

Table 9. Data comparison of precipitation time on $\mathrm{NaOH}$ and $\mathrm{Na}_{2} \mathrm{~S}$

\begin{tabular}{cccc}
\hline $\begin{array}{c}\text { Reagent } \\
\text { Type }\end{array}$ & $\begin{array}{c}\text { Precipitat } \\
\text { ion Time } \\
\text { (days) }\end{array}$ & $\begin{array}{c}\text { Precipitate } \\
\text { Mass (g) }\end{array}$ & $\begin{array}{c}\text { Ag in } \\
\text { Filtrate } \\
\text { (ppm) }\end{array}$ \\
\hline $\mathrm{NaOH}$ & 7 & 1.9018 & 1140 \\
$\mathrm{Na}_{2} \mathrm{~S}$ & 2 & 0.3151 & 12 \\
\hline
\end{tabular}

The smaller $K_{s p}$ results in the faster formation of precipitate. However, faster precipitation time did not affect the amount of silver recovery in the use of $\mathrm{Na}_{2} \mathrm{~S}$. If the silver was recovered based on precipitate mass and the remaining silver content in the filtrate, $\mathrm{NaOH}$ reagents are better than $\mathrm{Na}_{2} \mathrm{~S}$ reagents. That was because there is protonation in the $\mathrm{Na}_{2} \mathrm{~S}$ ionization reaction, which produces $\mathrm{H}_{2} \mathrm{~S}$. So that the formation of $\mathrm{Ag}_{2} \mathrm{~S}$ precipitate is less than the formation of $\mathrm{Ag}_{2} \mathrm{O}$. Therefore, in the filtrate with $\mathrm{Na}_{2} \mathrm{~S}$ precipitant, the nonrecoverable silver was still more than the $\mathrm{NaOH}$ precipitant. The following table 9 compares the precipitation time of optimum $\mathrm{NaOH}$ and $\mathrm{Na}_{2} \mathrm{~S}$ concentrations. 


\section{Results of XRF Analysis on Solids of $\mathrm{NaOH}$ Reagents}

The precipitate analyzed was the result of precipitation with the $2.5 \mathrm{M} \mathrm{NaOH}$ reagent. The analysis showed that in the precipitate there were no other elements besides $\mathrm{Ag}$ and $\mathrm{Br}$. The mass percentages of $\mathrm{Ag}$ and $\mathrm{Br}$ were $58.09 \%$ and $41.91 \%$, respectively. The following data shows the results of the precipitation analysis of the $2.5 \mathrm{M} \mathrm{NaOH}$ precipitant in table 10. These results state that there are no other impurities other than $\mathrm{Br}$ in the precipitate which interfere the precipitate mass.

Tabel 10. Data percentage of elemental masses in precipitate with $\mathrm{NaOH}$ precipitant

\begin{tabular}{ccc}
\hline Element & Mass\% & I-error\% \\
\hline $\mathrm{Ag}$ & 58.09 & 1.01 \\
$\mathrm{Br}$ & 41.91 & 0.30 \\
\hline
\end{tabular}

\section{Results of XRF Analysis on Solids of $\mathrm{Na}_{2} \mathrm{~S}$ Reagents}

In contrast to the results of XRF analysis on the precipitate using $\mathrm{NaOH}$, the precipitates of $\mathrm{Na}_{2} \mathrm{~S}$ contained $\mathrm{S}$ element content as much as $47.85 \%, \mathrm{Ag} 50.35 \%$, and $\mathrm{Br} 1.80 \%$. The existence of this element $\mathrm{S}$ is possible to form $\mathrm{Ag}_{2} \mathrm{~S}$ precipitate or Sulfur precipitate. Following are the results of XRF precipitation analysis and spectra with $\mathrm{Na}_{2} \mathrm{~S}$ precipitant in table 11 and figure 1.

Tabel 11. Data percentage of elemental mass in precipitate with $\mathrm{Na}_{2} \mathrm{~S}$ precipitant

\begin{tabular}{ccc}
\hline Element & mass\% & I-error\% \\
\hline $\mathrm{Ag}$ & 50.35 & 2.03 \\
$\mathrm{~S}$ & 47.85 & 2.34 \\
$\mathrm{Br}$ & 1.14 & 2.98 \\
\hline
\end{tabular}

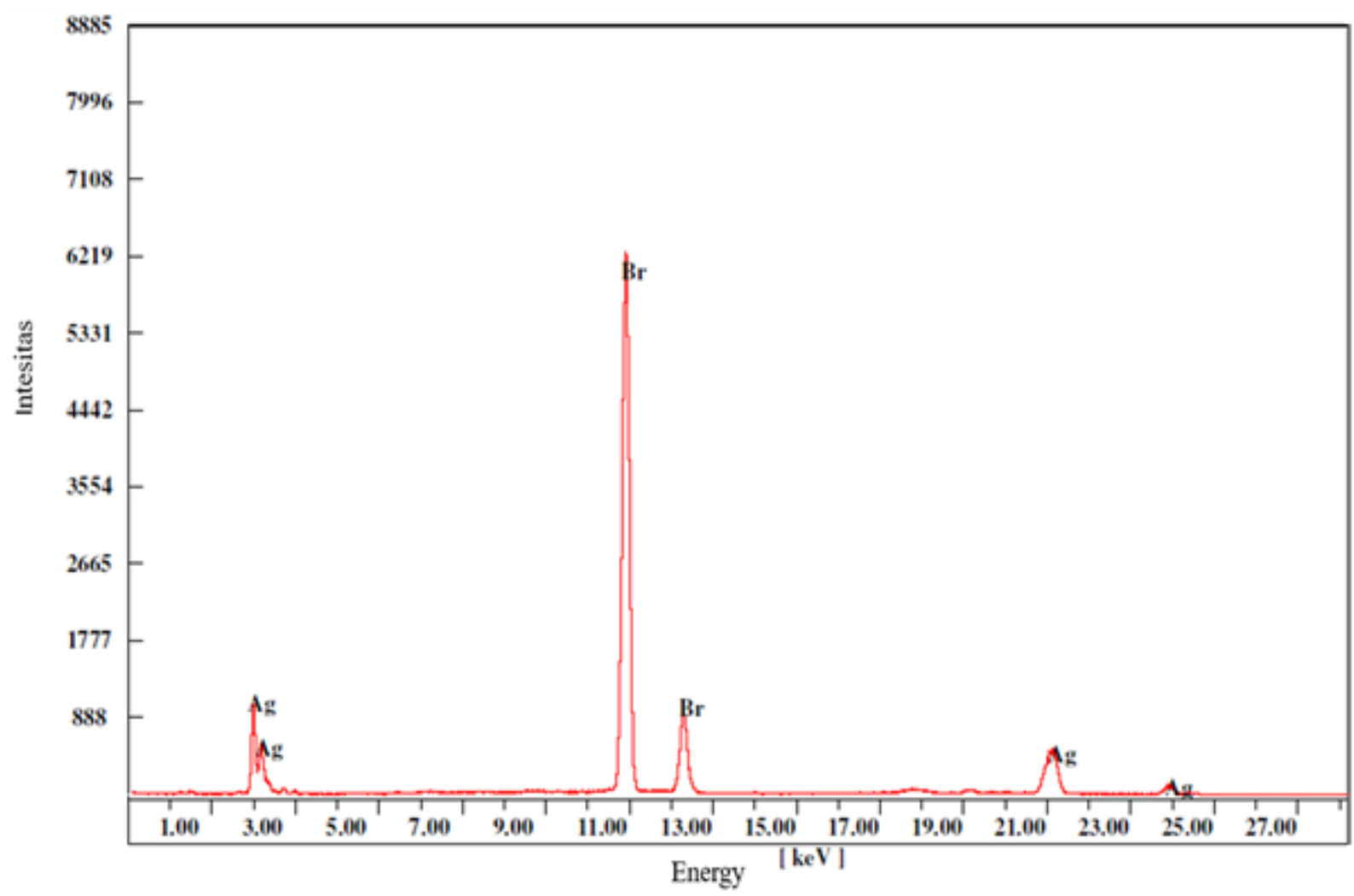

Figure 1. The spectra resulting from XRF analysis on $\mathrm{NaOH}$ precipitant 


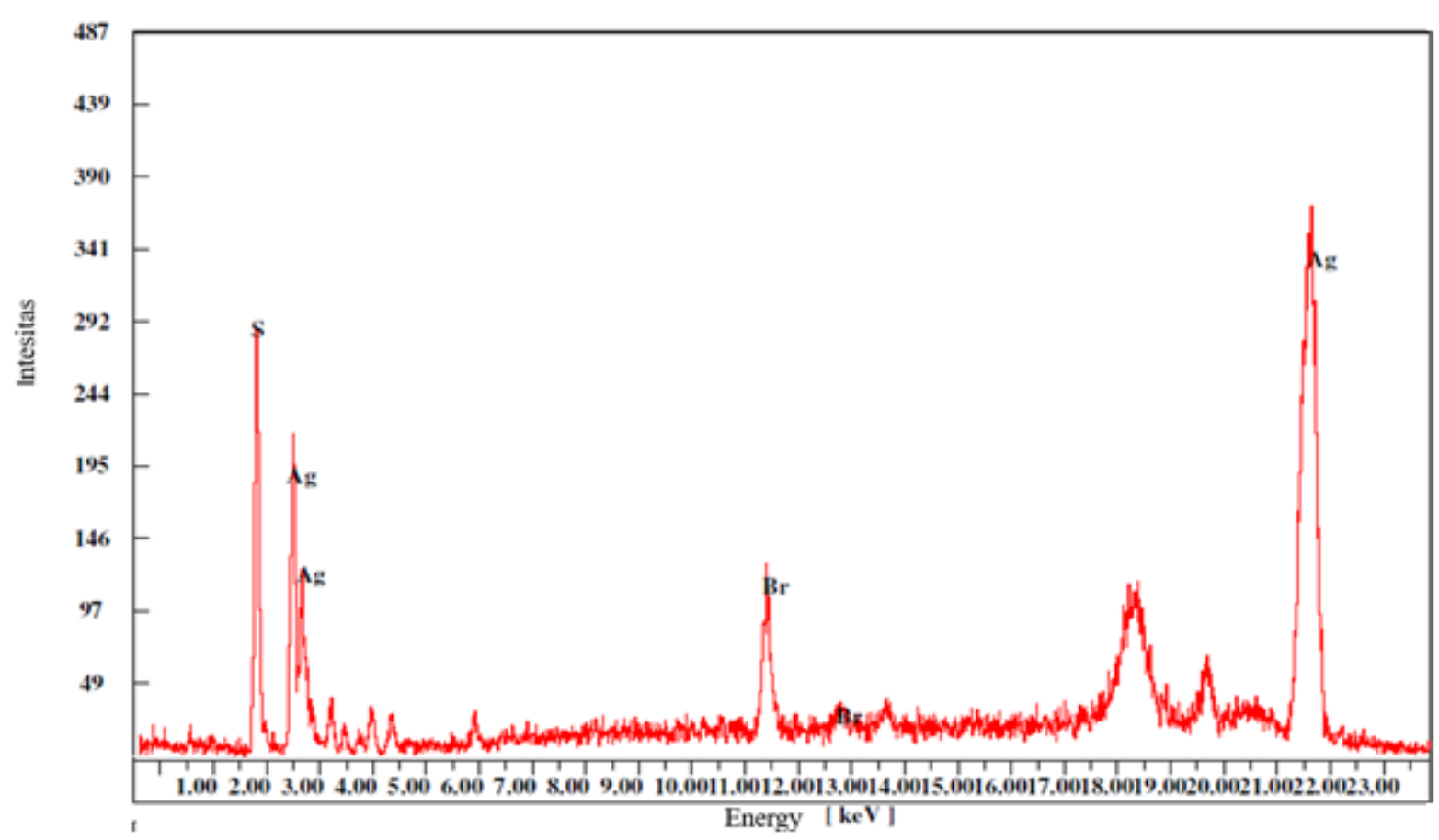

Figure 2. XRF spectra of precipitate with $\mathrm{Na}_{2} \mathrm{~S}$ precipitant. XRF spectra of precipitate with $\mathrm{Na}_{2} \mathrm{~S}$ precipitant

\section{CONCLUSION}

The optimum concentration of $\mathrm{NaOH}$ and $\mathrm{Na}_{2} \mathrm{~S}$ in silver recovery from $\mathrm{X}$-ray film waste by precipitation method was both at the concentration of $1.5 \mathrm{M}$ with the leaching temperature of the $\mathrm{NaOH}$ precipitant did not significantly affect the silver recovery. Whereas in the $\mathrm{Na}_{2} \mathrm{~S}$ precipitation the leaching temperature significantly influences the recovery silver, it can precipitate the leaching product faster than $\mathrm{NaOH}$, but resulted in the acquisition of less silver than the $\mathrm{NaOH}$.

\section{REFERENCES}

Army Medical. 2020. Composition of X-ray Film Processing. Diakses dari http://armymedical.tpub.com/MD0954/Co mposition-of-X-Ray-X-Ray-Film-

Processing-8.htm

Cânda LR, Ardelean E. 2017. Preliminary experimental research for silver recovery from radiographic films. In IOP Conference Series: Materials Science and Engineering. 163(1): 012-024.

Cânda LR, Ardelean E, Hepuț T, Ardelean M. 2018. Use of aqueous $\mathrm{NaOH}$ solutions to recover silver from radiographic films. In IOP Conference Series: Materials Science and Engineering. 416(1): 012-097).
Chang R. 2008. General Chemistry: The Essential Concepts. Boston(US): McGraw-Hill.

Chang R. 2005. Kimia Dasar: Konsep-konsep Inti Jilid 1 Edisi Ketiga. (Alih Bahasa: Departemen Kimia, Institut Teknologi Bandung). Jakarta(ID): Erlangga.

Goaz PW, White J. 1982. White Oral Radiology Principles and Interpretation (Edisi Kesatu). London(UK): Louise Toronto

Icky. 2011. Tahapan Pengolahan Film Secara Utuh. Jakarta(ID): Universitas Indonesia.

Istiyono E. 2008. Pengolahan limbah industri penyepuhan logam perak (elektroplating) di lingkungan pengrajin perak kecamatan kotagede. J. FMIPA dan PGSD FIP Univ. Negeri Yogyakarta. 12(2): 184-192.

Kesumayadi D, Sutanto H. 2015. Studi pengendapan perak pada limbah fixer yang telah jenuh dengan metode pembakaran dan pengendapan $\mathrm{NaOH}$ dan $\mathrm{Na}_{2} \mathrm{~S}$. Youngster Physics Journal. 4(1): 111-116.

Khunprasert P, Grisdanurak N, Thaveesri J, Danutra V, Puttitavorn W. 2008. Radiographic film waste management in thailand and cleaner technology for silver 
leaching. Journal of Cleaner Production. 16(1): 28-36.

Lange L, Triebel W. 2000. Sulfides, polysulfides, and sulfanes. Ullmann's Encyclopedia of Industrial Chemistry.

Nakiboğlu N, Toscali D, Nisli G. 2003. A novel silver recovery method from waste photographic films with $\mathrm{NaOH}$ stripping. Turkish Journal of Chemistry. 27(1): 127133.
Peraturan Pemerintah no. 85 tahun 1999 tentang baku mutu TCLP (Toxicity Characteristic Leaching Procedure).

Svehla G. 1985. Analisis Anorganik Kualitatif Makro Dan Semimikro. Edisi Kelima, Bagian I. Jakarta(ID): Kalman Media Pustaka.

Syed S, Suresha S, Sharma LM, Syed AA. 2002. Clean technology for the recovery of silver from processed radiographic films. Hydrometallurgy. 63(3): 277-280. 